\title{
THE ROLE OF CASH HOLDING IN INCREASING FIRM VALUE
}

\author{
Luluk Muhimatul Ifada \\ luluk.ifada@unissula.ac.id \\ Maya Indriastuti \\ Rustam Hanafi \\ Universitas Islam Sultan Agung \\ Jl. Kaligawe Raya, Terboyo Kulon, Kec. Genuk, Kota Semarang, Jawa Tengah 50112
}

received: 25/9/2020; revised: 22/10/2020; approved: 28/10/2020

\begin{abstract}
This study aims to examine the role of cash holding in mediating the effect of leverage on firm value. The object of this research is 423 manufacturing companies listed on the Indonesia Stock Exchange in 2016-2018. The sampling technique used in this research is purposive sampling, with the criteria of manufacturing companies listed on the Indonesia Stock Exchange in 20162018, publishing financial reports, and having complete data related to research variables so that a sample of 124 manufacturing companies was obtained. The analysis technique used in this research multiple linear regression analysis and path analysis. The results showed that leverage had a significant negative effect on cash holding and cash holding had a significant positive effect on firm value. Leverage has no significant positive effect on firm value. Cash holding is not able to mediate the effect of leverage on firm value.
\end{abstract}

Keywords: leverage; firm value; cash holding; pecking order theory; manufacturing companies

\section{INTRODUCTION}

The rise and fall of stock prices in the capital market is an interesting phenomenon to discuss regarding the issue of the ups and downs of firm value. This condition affects firm value, because it is reflected in the share price, as stated by Bigelli and Sánchez-Vidal (2012). Firm value is a certain condition achieved by the company as a reflection of public trust in the company after going through a process of activities for several periods since the company was built up to now. Increasing firm value is an achievement in accordance with the desires of the owners. By increasing the firm value, the welfare of the owners will also increase. Investors are also more interested in investing in companies that have a good performance in increasing firm value.

Firm value can be affected by leverage. Leverage is defined as an estimate of the risk inherent in a company (Gill and Shah, 2011). It means, the greater the leverage, the greater the investment risk. In meeting the needs of company funds, financial managers can choose alternative sources of internal and external funds. If the company is still able to exploit its internal funding sources, then the external sources of funding will not be exploited. It can be concluded that a high leverage ratio can cause a decrease in firm value (Akani and
Ifechi, 2017; Bigelli and Sánchez-Vidal, 2012). Its mean that a high level of debt, investors will judge that the company is in a state of credit failure, so that investors' interest in investing in the company will be lost and the firm value in the view of investors will decrease. Thus, leverage can have a negative effect on firm value.

Cash holdings in companies receive special attention in the field of financial literature. Of particular concern lies in the fact that companies hold significant amounts of cash on their balance sheets. Corporate cash holdings have been extensively studied in the financial literature (Jebran, et. al., 2019). Pinkowitz, et. al., (2016) argue that managers who maximize shareholder value will regulate the company's cash level in such a way that the marginal benefit of cash equals the marginal cost of owning the asset. Companies need cash for various reasons, such as for daily operations, to finance company growth through profitable operations, to pay taxes, and so forth (Kafayat, 2014).

Leverage can negatively affect cash holding (Jebran, et. al., 2019). Leverage is a substitute for cash. If the leverage is large, the company can hold cash holding at a low level. If the leverage is high, the company's cash will be pressed lower. This is because all internal company funding activities will be replaced 
with external funding. Debt is a cash substitution for investing, so when debt is large, cash holding is low.

Cash holding has an effect on firm value, if cash owned by a company is sufficient or not excessive (Nguyen and Le, 2016). Cash holding can also have a positive and significant impact on firm value, meaning that holding cash at a high level is necessary for potential investment opportunities that can be made by the company.

There is an effect of firm value related to cash holding issues, such as the relationship which states that cash holding is related to financial constraints. This theory considers cash holding as a company's flexibility in dealing with financial constraints. Companies experiencing financial constraints will hold larger cash holdings. There is a tradeoff between companies with external financing and cash holding. Companies with high debt costs are in a state of financial constraints that will cause the company to hold its cash at a higher amount. Based on the explanation, it is clear that companies with high cash holding can minimize the risk from external financing or high debt costs, thus making the condition of the company more stable which will make the firm value better.

Cash holding is interesting to study, as stated by Couderc (2005). Research on cash holding is still considered insufficient to prove the company's motivation to hold excess cash, so that this research is needed. There are two opposing views about the leverage variable which explains the relationship between leverage and firm value. Akani and Ifechi (2017) found that leverage has a negative effect on firm value. This is because the company does not use too much leverage, but rather uses the company's cash in the company's operations so that it does not have an impact on credit payment failure. In contrast to the results of research conducted by Rizqia and Sumiati (2013) that leverage has a positive effect on firm value. This means that if the leverage increases, the firm value will increase. Conversely, if the leverage decreases, the firm value will decrease.

Based on Jebran, et. al. (2019), leverage has a negative effect on cash holding, states that cash holding has a positive and significant effect on Firm Value. Thus, the researcher of this study will examine whether leverage has a direct or indirect effect on firm value through cash holding as a mediating variable.

This research is expected to be able to contribute both theoretically and practically. Theoretically, this research is expected to be a reference for future research. This research can support the pecking order theory, because the company will maximize firm value based on considerations of the costs and benefits of holding cash. This means, the company prefers to use its cash to pay off its debts. Practically, this research can contribute for management who realizes that cash holding management, because it affects firm value. The cash holding arrangement can increase investment in companies and subsequently have an impact on increasing firm value. Besides that the cash holding arrangement has a motive to encourage companies to hold cash and a motive to prevent financial distress.

The pecking order theory reveals a hierarchy in funding. According to Eugene (2012) internal funds are preferred over external funds because internal funds allow companies to no longer need to open themselves to the spotlight of outside investors. Pecking Order Theory in this study is used to explain the relationship between leverage and firm value. The most companies use internal funding rather than leverage in company operations and corporate funding, so that it does not have an impact on credit payment failure. It means, it can be adjusted to the Pecking Order Theory where the company chooses to use internal funding first for external funding because of the costs of information asymmetry and the risk of credit failure which can affect firm value. If the company has a high level of leverage and experiences credit failure, it can affect the firm value in the view of investors.

Trade off theory suggests that the company will maximize firm value based on considerations of the costs and benefits of holding cash. This means, the company prefers to use its cash to pay off its debts. Meanwhile, precautionary motives show that companies can collect more cash reserves to avoid future risks or to finance their activities and investments (Myers and Majluf, 1984). Trade off theory in this study is used to explain the relationship between cash holding and firm value. Cash holding has a significant influence on Firm Value. Cash holding at a high level is very necessary for the potential investment opportunities of a company, without sufficient internal funds in companies with high external financing can eliminate potential investment opportunities so that it will reduce firm value. Cash holding at a high level has a significant effect on firm value.

Firm value is the result of investors' assessment of the success rate of a company in relation to stock prices. According to Bigelli and Sánchez-Vidal (2012), the market price of company shares formed between buyers and sellers when a transaction occurs is called the company's market value. Since the stock market price is considered to be a reflection of the actual value of the company's assets, the firm value formed through the stock market value indicator is strongly influenced by investment opportunities.

The firm value is reflected in its share price. The higher the share value, the higher the firm value. High firm value is the desire of company owners, because high firm value shows that the prosperity of shareholders is also high.

Cash holding is the amount of cash ownership of the company. Cash is used as a buffer between retained earnings and investment needs. Basically, when maintained, the income is not sufficient to finance new 
investment, companies use cash holdings to do so, and in the last instance, they issue debt (Ferreira \& Vilela, 2004). In addition, there are fixed costs for accessing external funding, so companies rarely raise external capital and more often rely on cash holdings to fund projects (Pinkowitz, et. al., 2016). If the company's cash is sufficient or not excessive, it can indicate the company's liquidity. The definition of cash according to Skousen, et. al. (2009) is an item that is considered the same as cash, for example short-term securities that will mature soon and other highly liquid temporary investments. Bigelli and Sánchez-Vidal (2012), cash is a means of payment that is ready and free to be used to finance general company activities. Isshaq, et. al., (2009) found that the cash holding variable can be measured by the log of the year-end cash balance or cash equivalents.

Leverage is the company's policy on how far a company uses funding outside the company. By using leverage, companies can not only gain profits but also cause the company to experience losses, because financial leverage means that the company imposes risks on shareholders, thereby affecting stock returns according to (Copeland, 1992). High leverage indicates that the company is not solvable, meaning that its total leverage is greater than its total assets, as stated by (Brigham and Houston, 2007).

Leverage is the company's policy on how far a company uses funding outside the company. By using leverage, the company can not only gain profits but also cause the company to experience losses, because the use of leverage means that the company imposes risks on shareholders, thereby affecting stock returns. Therefore, there is negative relationship between leverage and cash holding. If the company has good access to the bond market, it can use debt as a substitute for the company's current assets, even though the company actually prefers to have high cash and low debt. Companies with high debt will use this debt to invest so that the amount of money held is small (Garcia-Teruel, et. al., 2009). Based on the statements of (Guney, et. al., 2007), it proves that leverage has a negative effect on cash holding. In fact, many previous studies have documented the negative relationship between leverage and cash holding (Ferreira and Vilela (2004); Pinkowitz, et. al. (2016); Bigelli and Sánchez-Vidal (2012); D’Mello, et. al. (2008)).

Leverage has a negative effect on firm value. This is because the company does not use external funding, but uses company cash in the company's operations so that it does not have an impact on credit failure in credit payments. Hence, it means, it can be adjusted to the Pecking Order Theory where the company chooses to use internal funding first and then external funding because of the cost of information asymmetry.

If the level of leverage is high, the firm value will decrease, because there is a risk of credit failure. Therefore, many companies use the company's operating cash rather than credit funds to avoid credit payment failure. If a company experiences a credit failure, it will reduce the interest of potential investors to invest in that company, because the ups and downs of the firm value are reflected in the share value. If the company has high leverage, potential investors will think about investing because they are afraid that the company will fail in credit payments. Based on the statement of Bigelli and Sánchez-Vidal (2012), leverage has a negative effect on firm value.

Cash is an asset that is ready to be converted into another type of asset. Trade Off Theory suggests that the company will maximize firm value based on considerations of the costs and benefits of holding cash. Cash is also the asset most susceptible to management's careless behavior. Cash can also attract investors where it is high, the company can make internal and external financing payments. When there is an investment opportunity, the company can use the cash to invest which results in an increase in firm value, so that it gives a good signal to potential investors who will invest. This statement is supported by (Nguyen and Le, 2016), which states that cash holding has a positive and significant effect on Firm Value.

Leverage is a substitute for Cash Holding. It means, the higher the leverage, the lower the Cash Holding of a company. Accounts payable is a cash substitution as a source of investment for the company. If the company can easily obtain funding sources from debt, the company can hold cash in low amounts. Meanwhile, companies with sufficient financial resources will use cash for the company's operational activities. When the debt matures, the company will need cash to pay off the debt, so companies with a high amount of leverage will need large amounts of cash. Cash is an asset that is ready to be converted into other types of assets. Trade Off Theory suggests that the company will maximize firm value based on considerations of the costs and benefits of holding cash. Cash is also the asset most susceptible to management's careless behavior. Cash can also attract investors where cash is high, the company can make internal and external financing payments. If there is an investment opportunity, the company can use the cash to invest so that it will increase the firm value and give a good signal to potential investors.

Cash holding has a positive effect on firm value. There is a tradeoff between companies with external financing and cash holding. Companies with high debt costs are in a state of financial constraints that will cause the company to hold its cash at a higher amount. Thus, it is clear that companies with high cash holding can minimize the risk from external financing or from high debt costs, so that it makes the condition of the company more stable which will make the firm value better and avoid credit failure (Jebran, et. al., 2019). Referring to the statement of (Jebran, et. al., 2019) that there is an negative effect of leverage on cash holding. 


\section{METHODS}

The type of data in this research is quantitative data. The data sources obtained from www.idx.co.id. The data were annual report in the period 2016-2018 cited by the leverage, cash holding, and firm value. It also obtained from various scientific articles, textbooks, and internet sources.

The population in this research is 423 manufacturing companies listed on the Indonesia Stock Exchange in 2016-2018 (141 manufacturing companies x 3 years). The sample of this research are selected by using purposive sampling method with criteria are: (1) manufacturing companies listed on the Indonesia Stock Exchange in 2016-2018, (2) Issued complete annual reports periodically since 2016 to 2018, and (3) Have complete data related to the variables used in the study, such as having Leverage, Cash Holding, and Firm Value in their financial statements. Based on these criteria, the total sample of manufacturing companies used in this study were 141 manufacturing companies (47 manufacturing companies $\mathrm{x} 3$ years).

Firm value is the result of an investor's assessment of the success rate of a company concerning stock prices. According to Bigelli and Sánchez-Vidal (2012), the market price of company shares formed between buyers and sellers when a transaction occurs is called the company's market value. Since the stock market price is considered to be a reflection of the actual value of the company's assets, the firm value formed through the stock market value indicator is strongly influenced by investment opportunities.

The firm value is reflected in its share price. The higher the share value, the higher the firm value. High firm value is the desire of company owners, because high firm value shows that the prosperity of shareholders is also high. The firm value is proxied by Tobin's Q which can be calculated by the equation as follows:

$$
\mathrm{Q}=\frac{\mathrm{EMV}+\mathrm{D}}{\mathrm{EBV}+\mathrm{D}}
$$

$\mathrm{Q} \quad=$ Firm Value

$\mathrm{EMV}=$ Equity Market Value

$\mathrm{D}=$ Book value of total debt at year end $\mathrm{EBV}=$ Equity Book Value

Equity Market Value (EMV) is obtained from the multiplication of the share price and the closing price at the end of the year with the number of shares outstanding at the end of the year. EBV is obtained from the difference between the company's total assets and total liabilities (Nguyen and Le, 2016).

Cash holding is the amount of the company's cash. If the cash the company has is sufficient or not excessive, it can indicate the company's liquidity. According to Gill and Shah (2011), cash is a means of payment that is ready and free to be used to finance general company activities. Cash Holding is denoted by the following formula:

$$
\text { Cash Holding }=\frac{\text { Cash }+ \text { Cash Equivalent }}{\text { Total Assets }}
$$

Leverage is the company's policy on how far a company uses funding outside the company. According to Iturriaga and Crisóstomo (2010) leverage is denoted by the following formula:

$$
\text { Leverage }=\frac{\text { Total Debt }}{\text { Total Assets }}
$$

Statistical analysis descriptive is employed to analyze the data. The classic assumption test is used to find out whether the data in this study is biased or not. It is often called BLUE (Best Linear Unexpected Estimator), tests include normality, multicollinearity, heteroscedasticity and autocorrelation test. The data analysis method used is linear regression analysis.

\section{RESULTS}

The sample in this study is 141 manufacturing companies listed on the Indonesia Stock Exchange 20162018 that was reduced by 17 outliers, so that the processed data were 124 data. Leverage, Cash Holding, and Firm Value indicate that the variable data is good (Table 1).

The results of regression test model 1 in Table 2 indicate that the coefficient of leverage variable is -6.383 with a significant level of 0.000 ; regression test model 2 , the coefficient of leverage variable is 1.612 with a significant level equal to 0.110 ; and the coefficient of cash holding variable is 2.750 with a significant level equal to 0.007 . Therefore, the leverage has a significant negative effect to cash holding, but a positive and insignificant effect to firm value. Cash holding has a significant positive effects to firm value. Thus, the first and third hypothesis are accepted, but the second hypothesis is rejected.

\section{DISCUSSION}

The results of this study show that leverage has a significant negative effect on cash holding. The higher the leverage of the company so the smaller the cash holding that company has. The results of this study support the trade off theory. The high leverage makes the company have a high interest expense. This makes the company optimize its existing debt to be immediately invested for profit. This investment optimization has resulted in more company funds being used for investment than as cash holding. So that there is a negative relationship between leverage and cash holding. Companies with high debt will use this debt to increase the amount of 
money they have to be small. It is feared that the high investment will come from debt that is at risk of default. The results of previous studies that are in line with the results of this study are research by Ferreira and Vilela (2004); Pinkowitz, et, al. (2006); Bigelli and SánchezVidal (2012); who argue that leverage has a significant negative effect on cash holding.

The results of this study show that leverage has insignificant effect on firm value. By using leverage, companies can not only gain profits but also cause the company to experience losses, because financial leverage means that the company imposes risks on shareholders, thereby affecting stock returns (Copeland, 1992). The trade-off theory associated with leverage and firm value states that leverage has a negative effect on firm value. In a certain proportion, the higher the leverage, the lower the company value. This is because higher leverage can lead to higher default risk and this results in lower firm value. The results of the study concluded that there was no effect of leverage on firm value. It is possible that the high level of debt in the sample companies can be managed by company management so that it does not affect the decline in firm value. The results of previous research that are in line with the results of this study are research Ibrahim (2020) which argues that leverage has insignificant effect on firm value. However, this study contradicts the research of Graham and Harvey (2001) and Guney et al. (2007), which argues that leverage has a negative effect on firm value.

The results of this study show that cash holding has a significant positive effect on firm value. It indicates that the increase in the number of cash holding issued affects the firm value. The results of this study support the trade off theory. In this study, the effect of cash holding on firm value is that cash can be optimally managed by the company, so that in the perception of investors, the company has sufficient cash holding. This will attract investors where cash is at a high enough level. This is also an indication that the company can make internal and external financing payments. When investing opportunities, companies can use these funds to help which can provide a good signal to potential investors who will develop. This results in an increase in company value. The results of previous research that are in line with the results of this study is the research conducted by Sola et al. (2011) which argues that cash holding has a significant positive effect on firm value.

From the sobel test results, the statistical test value is $-0.624<1.96$ with a two-tailed probability of $0.532>$ 0.05 . Thus, it can be interpreted that cash holding has not mediated between leverage and firm value. Leverage does not significantly affect firm value through cash holding as a mediating variable, because a high leverage ratio will sacrifice cash holding at a low level. Because the company's cash will be used by the company as a means of payment of obligations, the opportunity for the company to invest in the potential to increase the firm value will be lost, as will the use of cash as a means of payment for company obligations. Previous research results that is in line with the results of this study are research conducted by Ibrahim (2020) which revealed that leverage will have a positive effect on firm value without going through cash holding as a mediating variable.

\section{CONCLUSIONS}

Based on the results of the research, it can be concluded that leverage has a significant negative effect on cash holding and not significant effect on firm value, cash holding has a significant positive effect on firm value, and cash holding has not mediated between leverage and firm value. Leverage does not significantly affect firm value through cash holding as a mediating variable, because a high leverage ratio will sacrifice cash holding at a low level. Because the cash holding will be used by the company as a means of payment of obligations. Thus, the opportunity for the company to invest in the potential to increase the firm value will be lost, as will the use of cash as a means of payment for company obligations.

\section{REFERENCE}

Akani, H. W., \& Ifechi, K.-N. J. 2017. Effects of Capital Structure and Board Structure on Corporate Performance of Selected Firms in Nigeria. Indian Journal of Finance and Banking, 1(2), 1-16. https:// doi.org/10.46281/ijfb.v1i2.85

Bigelli, M., \& Sánchez-Vidal, J. 2012. Cash holdings in private firms. Journal of Banking and Finance, 36(1), 26-35. https://doi.org/10.1016/j. jbankfin.2011.06.004

Brigham, E. F., \& Houston, J. F. 2007. Fundamentals of financial management (Dasar-dasar Manajemen Keuangan). Engineering and Process Economics (Vol. 3). https://doi.org/10.1038/sj.ejhg.5200824

Copeland, J. F. W. T. E. 1992. Managerial finance. Dryden Press. Retrieved from https://www.worldcat. org/title/managerial-finance/oclc/23651561

Couderc, N. 2005. Corporate cash holdings: financial determinants and corporate governance. University of Paris Working Paper, 106-112. Retrieved from http://citeseerx.ist.psu.edu/viewdoc/download?do $\mathrm{i}=10.1 .1 .175 .6789 \& \mathrm{rep}=\mathrm{rep} 1 \&$ type $=$ pdf

D’Mello, R., Krishnaswami, S., \& Larkin, P. J. 2008. Determinants of corporate cash holdings: Evidence from spin-offs. Journal of Banking and Finance, 32(7), 1209-1220. https://doi.org/10.1016/j. jbankfin.2007.10.005

Eugene F. Brigham, J. F. H. 2012. Fundamentals Of Financial Management (13 edition). Cengage Learning. Retrieved from https://www.pdforigin. info/fundamentals-of-financial-management-pdf/ 
Ferreira, M. A., \& Vilela, A. S. 2004. Why do firms hold cash? Evidence from EMU countries. European Financial Management, 10(2), 295-319. https://doi. org/10.1111/j.1354-7798.2004.00251.x

García-Teruel, P. J., Martínez-Solano, P., \& SánchezBallesta, J. P. 2009. Accruals quality and corporate cash holdings. Accounting and Finance, 49(1), 95-115. https://doi.org/10.1111/j.1467629X.2008.00276.X

Gill, A., \& Shah, C. 2011. Determinants of Corporate Cash Holdings: Evidence from Canada. International Journal of Economics and Finance, 4(1), 70-79. https://doi.org/10.5539/ijef.v4n1p70

Graham, J. R., \& Harvey, C. R. 2001. The theory and practice of corporate finance: Evidence from the field. Journal of Financial Economics, 60(2-3), 187-243. https://doi.org/10.1016/S0304405X(01)00044-7

Guney, Y., Ozkan, A., \& Ozkan, N. 2007. International evidence on the non-linear impact of leverage on corporate cash holdings. Journal of Multinational Financial Management, 17(1), 45-60. https://doi. org/10.1016/j.mulfin.2006.03.003

Ibrahim, U. A. 2020. Effect of Financial Leverage on Firm Value: Evidence From Selected Firms Quoted on the Nigerian Stock Exchange. European Journal of Business and Management, 12(3), 124-135. https://doi.org/10.7176/ejbm/12-3-16

Isshaq, Z., Bokpin, G. A., \& Mensah Onumah, J. 2009. Corporate governance, ownership structure, cash holdings, and firm value on the Ghana Stock Exchange. Journal of Risk Finance, 10(5), 488-499. https://doi.org/10.1108/15265940911001394

Iturriaga, F. J. L., \& Crisóstomo, V. L. 2010. Do leverage, dividend payout, and ownership concentration influence firms' value creation? an analysis of Brazilian firms. Emerging Markets Finance and
Trade, 46(3), 80-94. https://doi.org/10.2753/ REE1540-496X460306

Jebran, K., Chen, S., \& Tauni, M. Z. 2019. Principalprincipal conflicts and corporate cash holdings: Evidence from China. Research in International Business and Finance, 49, 55-70. https://doi. org/10.1016/j.ribaf.2019.02.010

Kafayat, A. 2014. Interrelationship of biases: effect investment decisions ultimately. Theoretical and Applied Economics, 21(6), 85-110.

Myers, S. C., \& Majluf, N. S. 1984. Corporate financing and investment decisions when firms have information that investors do not have. Journal of Financial Economics, 13(2), 187-221. https:// doi.org/10.1016/0304-405X(84)90023-0

Nguyen, T. L. H., Nguyen, L. N. T., \& Le, T. P. V. 2016. Firm Value, Corporate Cash Holdings and Financial Constraint: A Study from a Developing Market. Australian Economic Papers, 55(4), 368-385. https://doi.org/10.1111/1467-8454.12082

Pinkowitz, L., Stulz, R. M., \& Williamson, R. 2016. Do U.S. firms hold more cash than foreign firms do? Review of Financial Studies, 29(2), 309-348. https://doi.org/10.1093/rfs/hhv064

Rizqia, D.A. and Sumiati, S.A., 2013. Effect of managerial ownership, financial leverage, profitability, firm size, and investment opportunity on dividend policy and firm value. Research Journal of Finance and Accounting, 4(11), pp.120-130.

Skousen, C.J., Smith, K.R. and Wright, C.J., 2009. Detecting and predicting financial statement fraud: The effectiveness of the fraud triangle and SAS No. 99. In Corporate governance and firm performance. Emerald Group Publishing Limited.

Sola, C. M., García-Teruel, P.J. and Martínez-Solano, P., 2011. Corporate cash holding and firm value. Applied Economics, 45(2), pp.161-170.

Table 1. Descriptive Statistics

\begin{tabular}{lccccc}
\hline & $\mathrm{N}$ & Minimum & Maximum & Mean & Std. Deviation \\
\hline Firm Value & 124 &, 34 & 2,69 & 1,2664 &, 63602 \\
Leverage & 124 &, 08 &, 88 &, 4237 &, 18226 \\
Cash Holding & 124 &, 00 &, 39 &, 1110 &, 10289 \\
\hline
\end{tabular}

Table 3. The Results of Simple Linier Regression

\begin{tabular}{llllccc}
\hline Model & Dependent Variable & Independent Variable & $\beta$ Unstandardized & $\mathrm{t}$ & $\mathrm{Sig}$ & Decission \\
\hline 1 & Cash Holding & Leverage & -.282 & -6.383 & .000 & H1 Accepted \\
& F Hitung & 1.341 & & & .000 & \\
& Adj. R Square & 0.224 & & & & \\
2 & Firm Value & Leverage & .573 & 1.612 & .110 & H2 Rejected \\
& & Cash Holding & 1.731 & 2.750 & .007 & H3 Accepted \\
& F count & 3.819 & & & .025 & \\
& Adj. R square & .044 & & & & \\
\hline
\end{tabular}

